\title{
STRATEGI KELESTARIAN IKAN ENDEMIK SIDAT DANAU POSO DALAM MEMPROMOSIKAN KEBUDAYAAN DAN PARIWISATA DI KABUPATEN POSO
}

\author{
Martho Harry Melumpi* \\ *Dosen Fakultas Pertanian Program Studi Agribisnis Universitas Kristen Tentena \\ Email : harrymelumpi@rocketmail.com
}

\begin{abstract}
Abstrak
Kabupaten Poso memiliki sejumlah daya tarik wisata yang belum dikembangkan secara optimal, diantaranya Danau Poso dan segala keunikannya serta produk olahan hasil perikanan masyarakat lokal yang belum di kembangkan secara baik.Daya tarik pariwisata di Kabupaten Poso adalah Danau Poso yang didalamnya hidup ikan endemik Sidat. Namun, beragamnya potensi objek dan daya tarik wisata saat ini ternyata belum mampu menjadikan kawasan wisata Danau Poso menjadi destinasi wisata unggulan bagi Kabupaten Poso. Oleh karena itu strategi kelestarian ikan sidat di Danau Poso pengembangannya membutuhkan arahan yang sesuai dengan potensi dan permasalahan serta kebijakan yang terkait pengembangan ikan sidat.Penangkapan berlebihan (overfishing) menguras sumber daya dan berdampak pada hilangnya sumber mata pencaharian nelayan sidat.Pemerintah diharapkan membuat kebijakan dalam mengatur perikanan tangkap sidat sedemikian rupa untuk mencegah terjadinya penangkapan berlebih, mencegah terkurasnya sumberdaya dan memaksimalkan keuntungan jangka panjang dari nelayan. Dengan tetap terjaganya ekosistem sidat ini akan mampu mempertahankan keindahan promosi pariwisata di kabupaten Poso sebagai warisan kepada anak cucu kita kelak.
\end{abstract}

Kata Kunci : Strategi, ikan endemik sidat, Kebudayaan dan Pariwisata

\begin{abstract}
Poso District has several optimal resources to use, and it is also very suitable for the needs of the people in Poso Regency, namely Lake Poso, in which live eel fish are endemic. However, the diversity of potential objects and attractiveness for the tourist destinations of Lake Poso is a leading tourist destination for Poso Regency. Therefore the strategy of fish bat in Lake Poso development requires direction that is in accordance with the potential and problems and policies related to eel fish. Overfishing drains resources and influence on the livelihoods of eel fishermen. Pemeratoriumsi makes policies in regulating fine-tuned catching fish to prevent excessive desire, prevent depletion of resources and long-term profits from fishermen. By maintaining this eel ecosystem will be able to maintain tourism in Poso district as a legacy for our children and grandchildren in the future.
\end{abstract}

Keywords : Strategy, eel endemic fish, Culture and Tourism

\section{PENDAhUluan}

Indonesia debagai salah satu negara tropis memiliki keanekaragaman hayati yang tinggi sebagai sumber bahan alami (natural product) yang berasal dari tumbuhan, hewan dan mikroorganisme yang dapat dimanfaatkan untuk bahan pangan. Tiga perempat wilayah Indonesia, terdiri atas lautan dengan luas wilayah perairan sebesar 5,8 juta $\mathrm{km} 2$, serta memiliki potensi sumber daya lestari 6,6 juta ton ikan per tahun. Di dalam perairan tersebut tersimpan berbagai spesies ikan juga tersimpan berbagai jenis mineral dan sumberdaya hayati lain yang tinggi nilai ekonominya (Racmaniar, 1996). Danau Poso merupakan sebuah ekosistem yang unik.Salah satu produk dari danau ini adalah ikan sidat. Dari data penelitian yang ada terdapat 5 jenis ikan sidat yang hidup didanau Poso, salah satu diantaranya adalah jenis Anguilla marmorata, dan menurut para ahli masih ada jenis sidat yang belum teridentifikasi. Sidat, oleh masyarakat lokal di wilayah Tentena menyebutnya dengan nama Sogili atau 
Masapi. Pemanfaatan sidat oleh masyarakat di pesisir danau Poso masih terbatas untuk dikonsumsi bagian dagingnya dan biasanya di jual ke penampung sidat.

Sidat (Anguilla sp) memiliki pola hidup katadromous yang artinya mengawali hidup di laut dalam, bertumbuh di perairan tawar, dan setelah matang kelamin akan kembali beruaya ke laut untuk memijah. Selain memiliki pola hidup yang unik, sidat juga populer sebagai makanan yang mewah karena memiliki nilai nutrisi yang baik.Meskipun perairan Danau Poso telah dikenal sebagai salah satu sentra produksi sidat, namun informasi ilmiah tentang keberadaan sidat dan tingkat pemanfaatannya belum banyak diungkapkan.Ikan sidat merupakan ikan endemik danau Poso. Ikan endemik adalah jenis ikan yang terdapat disuatu areal tertentu (sungai, danau, situs, pulau, negara, benua), (Limbong, $d k k$ 2012). Salah satu keunikan sidat Danau Poso dengan sidat lainnya adalah setelah berkembangbiak dilaut para anakkan sidat akan kembali lagi ke Danau Poso mengikuti siklus hidupnya. Berbagai penelitian belum berhasil menemukkan apa sebab mereka kembali lagi, mereka menduga "Naluri" dari ikan sidat yang membuatnya kembali lagi ke Danau Poso.

Siklus hidup sidat adalah misteri untuk jangka waktu yang sangat panjang dalam sejarah ilmiah perikanan.Sidat tumbuh besar di perairan tawar, setelah dewasa kembali ke laut untuk berpijah. Siklus hidupnya, setelah tumbuh dan berkembang dalam waktu yang panjang di perairan tawar, sidat dewasa yang lebih dikenal dengan yellow eel berkembang menjadi silver eel (matang gonad) yang akan bermigrasi ke laut untuk memijah.

Potensi sumberdaya alam bahari dan ekosistemnya dapat dikembangkan dan dimanfaatkan sebesar-besarnya bagi kesejeahteraan rakyat dengan tetap memperhatikan upaya konservasi dan rehabilitasinya. Sumberdaya alam yang dapat dimafaatkan sebagai pelestarian alam dan sekaligus sebagai objek wisata alam, adalah : taman laut, pesisir pantai, flora termasuk hutan, fauna, dan berbagai bentuk ekosistem khusus.

Indonesia merupakan salah satu pusat keanekaragaman hayati dunia. Berbagai jenis organisme baik tanaman, hewan maupun mikroorganisme tersebar luas dengan jumlah yang melimpah. Dalam organisme tersebut terkandung senyawa kimiawai hasil metabolisme sekunder yang digunakan sebagai upaya untuk mempertahankan hidupnya. Senyawa tersebut dikenal sebagai metabolit sekunder. Potensi senyawa metabolit sekunder yang ada merupakan putaka kimiawi (Chemical library) yang dapat dieksplorasi dan dijadikan rujukan untuk kajian upaya pemanfaatnnya (Wibowo et al., 2003). Salah satu sumber daya hayati yang belum optimal untuk dieksplorasi dan dimafaatkan adalah ikan sidat.

Ikan sidat merupakan ikan yang penyebarannya sangat luas yakni di daerah tropis dan sub tropis sehingga dikenal adanya sidat tropis dan sidat sub tropis. Di dunia paling sedikit terdapat 17 spesies ikan sidat (Tesch, 1977), dan paling sedikit enam jenis diantaranya yakni : Anguilla marmorata, A. Celebensis, A. Ancentralis, A. Borneensis, A. Bicolor bicolor, dan A. Bicolor pacifica terdapat di Indonesia. Jenis ikan tersebut menyebar di daerah-daerah yang berbatasan dengan laut dalam yakni di pantai selatan pulau Jawa, pantai barat P. Sumatera, pantai timur P. Kalimantan, Bali, Nusa tenggara Barat dan Nusa Tenggara Timur hingga pantai utara Papua. Ikan sidat hidup diperairan estuari (laguna) dan perairan tawar (sungai, rawa dan danau serta persawahan) dari dataran rendah hingga dataran tinggi.

Sebagaimana telah diungkapkan
sebelumnya bahwa sebagian besa masyarakat Indonesia belum mengenal bentuk/rupa ikan sidat dan mencicipi rasanya. Agar ikan sidat dapat dikenal dan dapat diterima sebagai konsumsi oleh masyarakat maka dilakukan pengenalan produk-produk olahannya kepada masyarakat. Disamping itu, ada kesan bahwa sidat lebih mirip ular ketimbang ikan, menyebabkan timbulnya respon yang kurang baik dimasyarakat. Salah satu usaha mengubah kesan seperti ular tadi adalah dengan mengolahnya menjadi abon sidat, dendeng sidat, sosis sidat dan makanan khas Poso yaitu Onco arogo yang dapat menarik para wisatawan lokal maupun domestik. Dengan dibuat aneka olahan produk dari ikan sidat, diharapkan konsumsi masyarakat terhadap sidat dapat ditingkatkan, 
apalagi daging sidat memilki rasa yang khas dan gurih serta memiliki manfaat kesehatan sebagai antikoagulan.

Berbanding terbalik dengan kita di Indonesia yang memiliki keanekaragaman sumber daya hayati perairan yang sangat tinggi, jika dibandingan masyarakat penghasil ikan sidat di wilayah Kabupaten Poso, ikan sidat yang didapatkan kebanyakan tidak dikonsumsi secara langsung. Mengapa demikian?, salah satu faktor yang menyebabkan adalah faktor ekonomi dimana harga $1 \mathrm{~kg}$ ikan sidat dijual ke penampung seharga Rp. 115.000,00 sedangkan biaya tersebut sudah dapat mencukupi kebutuhan sehari-hari dari pada mengkonsumsi ikan sidat. Hal ini juga kiranya dapat menjadi "Pekerjaan Rumah" bagi kita peneliti dan pemerintah. Di negara Jepang sendiri harga per $1 \mathrm{~kg}$ ikan sidat dihargai Rp. 300.000,00 dan merupakan makanan mahal dan mewah sehingga kita lebih banyak mengeksportnya daripada memanfaatkan dan membudidayakannya. Makalah ini memuat pemikiran-pemikiran sederhana tentang upaya dalam meningkatkan pemafaatan ikan sidat di kabupaten Poso.

\section{METODE PENELITIAN}

Penelitian ini merupakan penelitian kualitatif yang bersifat deskriptif. Metode pengumpulan data dilakukan dengan survei primer melalui pengamatan dan survei sekunder dengan kajian literatur dokumen instansi, pustaka baku, dan penelusuran online. Studi literatur adalah cara yang dipakai untuk menghimpun data-data atau sumber-sumber yang berhubungan dengan topik yang diangkat dalam suatu penelitian. Data-data yang sudah diperoleh kemudian dianalisis dengan metode analisis deskriptif. Metode analisis deskriptif dilakukan dengan cara mendeskripsikan fakta-fakta yang kemudian di susul dengan analisis, tidak semata-mata menguraikan, melainkan juga memberikan pemahaman dan penjelasan secukupnya.

\section{HASIL DAN PEMBAHASAN}

Potensi sumberdaya ikan sidat yang ada di Kabupaten Poso cukup besar namun singkat pemanfaatannya belum optimal.Sebenarnya sumberdaya ikan sidat ini mampu memberikan manfaat yang signifikan bagi masyarakat memalui penciptaan lapangan usaha dan penyerapan tenaga kerja dalam kegiatan-kegiatan penangkapan, budidaya, pengolahan dan tataniaganya apabila ditangani secara sungguh-sungguh dan bijaksana.Untuk itu perlu dilakukan upaya-upaya yang sistemmatis dan rasional ke arah pemanfaatannya dengan tetap memperhatikan aspek kelestarian sumberdaya dan berkelanjutan.

Potensi sumberdaya ikan sidat yang cukup besar namun pemanfaatannya belum optimal sebenarnya mampu memberikan manfaat yang signifikan bagi masyarakat. Upaya yang dapat dilakukan dalam meningkatkan pemanfaatan sumberdaya ikan sidat adalah dengan beberapa strategi sebagai berikut :

\section{Inventarisasi Potensi Sumberdaya} Ikan Sidat Danau Poso

Data tentang penyebaran dan potensi ikan sidat perlu dikumpulkan dan dianalisis.Pada saat ini data-data hasil penelitian tersebar di beberapa perguruan tinggi dan lembagalembaga penelitian serta lembaga lainnya. Apabila dihimpun, akan tampak di lokasilokasi mana saja yang masih harus dilakukan inventarisasi dan informasi apa saja yang masih harus dikumpulkan sehingga datanya dapat dipetakan. Kegiatan inventarisasi ini harus dilakukan hingga dihasilkannya suatu "Peta distribusi dan potensi ikan sidat di Danau Poso".Melalui peta tersebut pengguna dapat mengetahui dengan mudah mengenai penyebaran jenis, kelimpahan dan stadia ikan sidat yang ada di perairan Danau Poso.

\section{Sosialisasi Pemanfaatan Sumberdaya Ikan Sidat Kepada Masyarakat}

Sebagaimana telah diungkapkan sebelumnya bahwa sebagian besar masyarakat Indonesia belum mengenal bentuk / rupa ikan sidat dan mencicipi rasanya. Agar ikan sidat dapat dikenal dan dapat diterima sebagai ikan konsumsi oleh masyarakat secara luas maka harus ada usaha-usaha penebaran ikan sidat di daerah-daerah yang secara alami tidak 
mungkin akan didapatkan ikan sidat. Benih ikan sidat yang ditebar di suatu perairan (sungai, rawa dan danau) akan tumbuh dan ketika suatu saat tertangkap oleh pemancing atau penangkap ikan, maka mereka akan berusaha untuk mengenalinya (mengenal / mengetahui nama jenisnya) dan akan mencoba untuk mengkonsumsinya. Melalui usaha ini, lambat laun masyarakat akan menerima ikan sidat sebagai ikan konsumsi. Apabila masyarakat telah mengenal dan menerima ikan sidat sebagai ikan konsumsi, selanjutnya diharapkan masyarakat akan membutuhkan ikan tersebut dan ikan ini menjadi komoditas yang diperjualbelikan di pasar lokal. Sejalan dengan usaha penebaran ikan sidat di perairan-perairan umum, dilakukan pula pengenalan produk-produk olahannya kepada masyarakat (misalnya: dendeng sidat, pepes, presto, sop, kobayaki, sidat asap dan lain-lain), baik melalui media masa elektronik maupun media masa cetak dan pameran-pameran. Salah satu kuliner khas poso menu sidat adalah arogo onco sidat yang makanan ini anda hanya dapatkan ketika berkunjung ke kota wisata Tentena, kabupaten Poso.

Kegiatan ini membutuhkan waktu yang cukup lama (3 - 5 tahun), namun harus dilakukan bila ingin agar masyarakat mengenal, menyenangi dan membutuhkannya. Sasaran akhir dari kegiatan ini adalah meningkatkan permintaan masyarakat akan ikan sidat. Apabila permintaan ikan ini telah meningkat maka untuk memenuhinya otomatis akan memacu kegiatan penangkapan di tempat yang merupakan daerah penyebarannya dan juga akan memacu kegiatan budidayanya. Ikan sidat adalah ikan yang bersifat katadromos artinya ikan ini akan beruaya ke laut dalam ketika akan bereproduksi. Karena ikan ini tidak mungkin berkembangbiak di lokasi yang kita tebari, maka upaya penebaran ikan ini harus dilakukan secara berulang kali. Dalam hal kegiatan penebaran (stocking) ke perairan umum, perlu di awali dengan uji coba pada perairan yang luasnya terbatas (misalnya di situ) dan dikaji dampaknya terhadap populasi jenis ikan lain yang ada di perairan tersebut. Dari kajian ini diharapkan akan diperoleh informasi mengenai dampak (positif atau negatif) dari kegiatan stocking tersebut. Stocking benih ikan sidat ini nantinya diharapkan selain akan dikenali oleh masyarakat juga akan mampu meningkatkan produksi ikan sidat dari perairan umum sebagaimana yang telah dilakukan di Australia.

\section{Pengembangan Teknik} Penangkapan Ikan Sidat di Perairan Umum

Apabila ikan sidat telah dikenal dan dibutuhkan oleh masyarakat maka kegiatan penangkapan ikan sidat di perairan umum akan meningkat. Untuk mengarahkan agar kegiatan penangkapan ini tidak bersifat destruktif bahkan mengancam kelestariannya maka perlu diperkenalkan teknik penangkapan yang sederhana dan ramah lingkungan. Di samping itu juga perlu dipikirkan dari awal, upaya-upaya konservasi di lokasi-lokasi tertentu yang merupakan jalur ruaya reproduksi ikan tersebut sehingga proses recruitment ikan tersebut tidak terganggu.

\section{Pengembangan Teknik Budidaya}

\section{Ikan Sidat}

Sejalan dengan upaya sosialisasi ikan sidat kepada masyarakat, upaya pengenalan teknik budidayanya pun perlu dilakukan.Teknik budidaya sidat yang perlu diperkenalkan kepada masyarakat (petani ikan) adalah teknik budidaya yang sederhana yang tidak membutuhkan banyak modal.Agar biaya produksi pada budidaya ikan sidat relatif rendah maka petani perlu diberi informasi yang memadai mengenai pakan sidat. Hal ini karena $50-60 \%$ dari biaya produksi berasal dari komponen pakan, sehingga apabila pakan sidat murah maka biaya produksi akan menjadi murah (rendah). Ikan sidat merupakan ikan karnivora murni yang membutuhkan pakan berupa hewan lain. Apabila ikan tersebut diberi pakan buatan maka kadar protein pakannya harus tinggi (> 45\%) sehingga harga pakannya mahal, hal ini akan menyebabkan biaya produksi dalam budidaya sidat menjadi tinggi sehingga harga sidat bila di jual akan tinggi pula dan ini akan menghambat sosialisasi ikan sidat sebagai ikan konsumsi masyarakat. Untuk menyiasati agar biaya produksi rendah, maka petani harus dibiasakan untuk mulai menggunakan sumber-sumber protein yang saat ini melimpah namun tidak / belum dimanfaatkan secara maksimal, misalnya: keong mas, limbah pengolahan ikan dan ternak atau 
hewan lain yang dapat dibudidayakan secara sederhana dan murah (misalnya: bekicot, cacing tanah dan lain-lain). Pengembangan teknik budidaya sidat sederhana yang dilakukan oleh masyarakat (petani kecil) dengan skala usaha relatif kecil tetapi pelaksananya (jumlah petani yang terlibat) banyak diharapkan pada akhirnya mampu menghasilkan produksi ikan sidat yang cukup besar dengan harga yang relatif rendah sehingga terjangkau oleh masyarakat.

Bilamana petani-petani ikan sidat telah banyak jumlahnya dan produksi dari hasil budidayanya telah cukup tinggi dan stabil maka produksi yang tadinya untuk tujuan konsumsi lokal dapat dialihkan ke tujuan ekspor.Agar supaya mutu produk petani dan kontinuitas produksi lebih terjamin maka petani ikan perlu menghimpun diri dalam asosiasi-asosiasi yang mampu mandiri dan mampu mengembangkan usahanya ke arah yang lebih maju.Bersamaan dengan pengembangan budidaya di masyarakat dan oleh masyarakat, lembaga penelitian dan perguruan tinggi harus melakukan penelitianpenelitian yang mengarah pada pemecahan masalah-masalah yang dihadapi oleh petani pelaksana dan penciptaan teknologi yang lebih maju dengan tidak mengesampingkan aspek produktivitas dan efisiensi.

Bersamaan dengan pengembangan budidaya ikan sidat dimasyarakat, lembaga penelitian dan perguruan tinggi harus melakukan penelitian-penelitian yang mengarah pada pemecahan masalah-masalah yang dihadapi oleh petani pelaksana dan pencipta teknologi yang lebih maju dengan tidak mengesampingkan aspek produktifitas dan efesiensi.Peran generasi muda didalamnya sangatlah dibutuhkan untuk tetap melestarikan habitat dari ikan sidat ini, diantaranya memberikan penyuluhan kepada para nelayan yang memiliki tangkapan ikan yang oleh masyarakat lokal disebut dengan "Waya Masapi".Aktifitas waya masapi ini adalah salah satu bentuk kerafian lokal masyarakat yang tinggal disekitar pinggiran Danau Poso. Mereka meletakan "Waya Masapi" ditengah-tengah danau dan tidak memberikan tempat bagi sidat yang akan melakukan pemijahan dilaut. Akibatnya adalah spesis sidat tersebut hanya sampai ditangan para petani nelayan, hal ini mengakibatkan terancamnya kepunahan ikan sidat. Oleh karena itu perlu adanya kerja sama antara pemerintah dan para nelayan untuk melakukan sosisalisai. Melalui beberapa strategi pemanfaatan ikan sidat yang sudah dikemukakan diatas tadi pariwisata di kabupaten Poso akan memiliki kualitas yang bermutu dan dijadikan salah satu wisata andalan Kabupaten Poso Sulawesi Tengah bahwa strategi pemanfaatan ikan endemik sidat Danau Poso dapat meningkatkan kesejahteraan rakyat melalui pariwisata ekonomi kreatif.

\section{KESIMPULAN DAN SARAN}

\section{Kesimpulan}

1) Tingkat pemanfaatan sumberdaya ikan sidat di perairan danau Poso masih sangat kurang sehingga status pemanfaatnya masih perlu pengkajian kembali

2) Potensi bahari danau Poso dijadikan sebagai kawasan ekowisata berdasarkan aspek-aspek pendukungnya.

\section{Saran}

Perlu adanya pelatihan dan sosialisasi pemanfaatan sumberdaya ikan sidat kepada masyarakat dalam menunjang nilai ekonomis ikan sidat dan daya dukung pariwisata dan budaya dan tetap menjunjung tinggi nilai-nilai kearifan sosial masyarakat serta sebagai bahan pertimbangan untuk membangun wisata bahari yang berkelanjutan.

\section{REFERENSI}

Limbong, D., Melumpi M, Mberato Y, Dosi F. 2012. Biostatistik Sidat Perak Danau Poso. Jurnal Riset Unkrit, Vol 1, No. 1, 2012:1-9.

Tesch, F.W. 1977. The eel biology and management of anguilla eels. Chapman and Hall. London. 434 p.

Racmaniar, 1996, Produk Alam laut sebagai Lead Compound untuk Farmasi dan Pertanian, Dibawakan pada Seminar Sehari Perspeltik Baru dalam drug Discovery, Makassar, 26 Oktober 1996. 
